\title{
Depletion of one, six, twelve or twenty major blood proteins before proteomic analysis: The more the better?
}

\author{
Stéphane Roche $e^{a, b}$, Laurent Tiers ${ }^{b}$, Monique Provansal $^{b, c}$, Martial Seveno ${ }^{d}$, \\ Marie-Thérèse Piva ${ }^{a, c}$, Patrick Jouin ${ }^{d}$, Sylvain Lehmann ${ }^{a, b, c, *}$ \\ ${ }^{a}$ CHU Montpellier, Biochimie Saint Eloi, Plateforme de Protéomique Clinique 80 av A. Fliche, 34295 Montpellier Cedex 5, France \\ binstitut de Génétique Humaine du CNRS, 141 rue de la Cardonille, 34396 Montpellier, France \\ ${ }^{\mathrm{c}}$ Université Montpellier 1, F-34000, Montpellier, France \\ ${ }^{\mathrm{d}}$ Plate-forme de Protéomique Fonctionnelle, IFR3, CNRS-UMR 5203, INSERM-U661, Univ. Montpellier I, Univ. Montpellier II, 141 rue de la \\ Cardonille, 34094 Montpellier Cedex 5, France
}

\section{A R T I C L E I N F O}

Keywords:

Immunocapture

Blood

Serum

Proteomics

Profiling

\begin{abstract}
A B S T R A C T
Depletion of major blood proteins is one of the most promising approaches to access low abundant biomarkers using proteomics. Immunocapture columns often used for this purpose exist in different formats depending on the number of major proteins removed. In this article, we compared the relative interest of depleting either one (albumin), six (albumin, IgG, IgA, transferrin, $\alpha 1$-antitrypsin, and haptoglobin), twelve (the previous six and apo A-I and -II, orosomucoid, $\alpha 2$-macroglobulin, fibrinogen, IgM) or twenty blood proteins (the previous twelve and IgD, ceruloplasmin, apo B, complement C1q, C3, C4, plasminogen, and prealbumin). Such study raises interesting issues related to the reproducibility, practicability, specificity of the immunocapture, and to the impact of removing not only the selected molecules, but also associated peptides and proteins. Depleted sera were here analysed using different proteomic approaches, including two dimensional electrophoresis and SELDI-TOF. Altogether, our results clearly confirmed the interest of depleting major blood proteins for the proteomic detection of low abundant components. However, we observed that increasing the number of depleted proteins from twelve to twenty had a limited beneficial impact and might increase drawbacks in removing associated peptides and proteins. This conclusion is however related to the technologies that we have used, and we believe that it is necessary to adapt the immunocapture to the analytical method employed, and to the ratio between wanted and unwanted proteins removed.
\end{abstract}

(C) 2009 Elsevier B.V. All rights reserved.

\section{Introduction}

Proteomic analysis of serum and plasma is of major interest for the identification and the detection of new clinical bio- markers. Many studies are focusing on these fluids to detect the presence of peptides and proteins which changes in concentration or post-translational modification are linked to a particular disease state. However, the proteomic analysis of

\footnotetext{
* Corresponding author. CHU Montpellier, Biochimie Saint Eloi, 80 av A. Fliche, 34295 Montpellier Cedex 5, France. Tel.: +33 499619931 ; fax: +33499619931.

E-mail address: Sylvain.Lehmann@igh.cnrs.fr (S. Lehmann).
} 
these blood fractions is analytically challenging due to the high dynamic concentration range (over 10 orders of magnitude) of constituent protein/peptide species [1]. Difficulties are even increased by the fact that the most abundant proteins that constitute $95 \%$ of the bulk mass of proteins represent less than $0.1 \%$ of the total number of proteins. Serum and plasma have a very high concentration of proteins, typically in the range of $50-80 \mathrm{~g} / \mathrm{L}$ and the abundant proteins like albumin produce in most proteomic approaches large signals which mask or interfere with the detection of low amount protein components.

To minimize these problems, proteomic techniques are constantly improving to access to a wider range of low concentration candidates [2,3]. Many methods rely on a multidimensional separation scheme combining for example multidimensional chromatography and electrophoresis or mass spectrometry (MS) methods [4,5]. This is the case of the Surface-Enhanced Laser Desorption/Ionization Time-of-flight (SELDI-TOF) method [6,7] that relies on MS to detect proteins and peptides initially retained by binding to various chromatographic surfaces (anionic, cationic, IMAC, hydrophobic).

When dealing with complex biological fluid like blood, most available proteomic technologies will however benefit from the preanalytical use of various pre-fractionation techniques [8]. They are represented for example by liquid chromatography [9], binding to solid-phase libraries [10,11], enrichment of low molecular weight proteins [12] or the prior removal of major proteins. The latter is often achieved using immobilized dye [13,14] or immunoaffinity [15-17]. Ideally, a depletion technique should be selective and remove $100 \%$ of the targeted protein (or proteins) without retaining non-targeted proteins. A number of commercial products have been designed for the depletion of several proteins from human or mammals serum and plasma. Most of the products are based upon specific antibodies to the high-abundance proteins present in these fluids. In theory, to access to low abundant biomarkers, the more high-abundance proteins that can be removed or depleted in a single experiment, the better. This general assumption is based at the peptide level diversity by LC-MS/ MS analysis of the tryptic digest of plasma proteins after 6 vs. 12 protein immunoaffinity subtraction [18], and in the case of cerebral spinal fluid using plasma-designed 6 vs. 20 different antibody sites on a single column [19]. Nevertheless, issues like reproducibility, practicability, specificity of the immunocapture, impact of removing not only the selected molecules, but also peptides and proteins associated with them, need to be carefully taken into account. In this manuscript we described for the first time in parallel, the comparison of different commercial columns capturing either one (albumin), six (albumin, IgG, IgA, transferrin, $\alpha 1$-antitrypsin, haptoglobin), twelve (the previous six and apo A-I and-II, orosomucoid, $\alpha 2$-macroglobulin, fibrinogen, IgM) or twenty blood proteins (the previous twelve and IgD, ceruloplasmin, apo B, complement C1q, C3, C4, plasminogen, and prealbumin). Depleted sera were analysed using different proteomic approaches including two dimensional electrophoresis and SELDI-TOF. Altogether, our results clearly confirmed the utility of depleting major blood proteins for the proteomic detection of low abundant components. However, we observed that increasing the number of depleted proteins from twelve to twenty had a limited beneficial impact and might increase drawbacks in removing associated peptides and proteins.

\section{Materials and methods}

\subsection{Serum samples}

Pooled anonymized clinical human samples from a methodological biobank declared to the legal French authorities under the number DC-2008-417 (August 2008) were used. Blood was initially collected in Vacutainer tubes without additive, let it clot for $30 \mathrm{~min}$ at room temperature and centrifuge for $30 \mathrm{~min}$ at $3000 \mathrm{~g}$. Serum was recovered and frozen at $-80^{\circ} \mathrm{C}$ until used.

\subsection{Major protein removal}

Major protein removal was performed using 1, 6, 12 and 20 proteins depletion columns as follows (see Table 1): albumin depletion alone (Beckman Ref. A25522), depletion of 6 proteins (albumin, IgG, IgA, transferrin, $\alpha 1$-antitrypsin, haptoglobin, Agilent Technologies Ref. 5188-5230), depletion of 12 proteins (the previous 6 and apo A-I and -II, orosomucoid, $\alpha 2$-macroglobulin, fibrinogen, and IgM, Beckman Ref. A24618), depletion of 20 proteins (the previous twelve and $\operatorname{IgD}$, ceruloplasmin, apo B, complement C1q, C3, C4, plasminogen, and prealbumin, Sigma Aldrich Ref. PROT20). Fractionation of serum proteins was performed as described by the manufacturers using buffers provided with the columns (Table 1). Briefly, serum was mixed in dilution buffer, filtered at $0.22 \mu \mathrm{m}$, added to immunoaffinity microbead spin column and incubated at room temperature. The unbound proteins were then collected by centrifugation. After washes with the dilution buffer, bound proteins were eluted in one or two steps with the stripping buffer. After depletion, the unbound proteins were concentrated and submitted to a buffer exchange with $50 \mathrm{mM}$ Tris $\mathrm{pH}$ 8.8 at $4{ }^{\circ} \mathrm{C}$ by a 45 min centrifugation on PES ultrafiltration columns with a $3 \mathrm{kDa}$ cut-off (Vivaspin 500, Vivascience ref VS0192) for SELDI-TOF and $10 \mathrm{kDa}$ cut-off (Vivaspin 500, Vivascience) for electrophoresis. Protein quantitation was performed using BCA kit (Sigma Aldrich). Both the standard curve and the samples before and after immunodepletion were diluted in $50 \mathrm{mM}$ Tris $\mathrm{pH} 8.8$ prior the analysis.

\subsection{SDS-PAGE electrophoresis}

NuPAGE Electrophoresis system (Invitrogen) was used. Briefly, following the manufacturer procedure, $60 \mu \mathrm{g}$ of protein in $30 \mu \mathrm{l}$ of LDS buffer $1 \mathrm{X}$ were loaded on $4-12 \%$ gradient gel. The running buffer used was MOPS and the migration was performed under $100 \mathrm{~V}$ current during $1 \mathrm{~h}$. Proteins were stained by colloidal Coomassie following manufacturer procedure (GelCode, Fermentas) and the gels were scanned using an Epson 1680 scanner.

\section{4. $2 \mathrm{D}$ electrophoresis}

Samples were recovered in $200 \mu$ l of solubilising buffer (8 M urea, $1 \mathrm{M}$ thiourea, $4.8 \% \mathrm{CHAPS}, 50 \mathrm{mM} \mathrm{DTT})$. For the first 
Table 1 - Description of the different commercial kits and their characteristics as indicated by the manufacturers.

\begin{tabular}{|c|c|c|c|c|}
\hline Column & 1 & 6 & 12 & 20 \\
\hline Capacity (serum) & $20 \mu \mathrm{l}$ & $14 \mu \mathrm{l}$ & $10 \mu \mathrm{l}$ & $8 \mu \mathrm{l}$ \\
\hline Unbound elution buffer & $\begin{array}{l}10 \mathrm{mM} \text { Tris- } \mathrm{HCl}, \mathrm{pH} 7.4, \\
150 \mathrm{mM} \mathrm{NaCl}\end{array}$ & Undisclosed buffer composition & $\begin{array}{l}10 \mathrm{mM} \text { Tris- } \mathrm{HCl} \text {, } \\
\mathrm{pH} 7.4,150 \mathrm{mM} \mathrm{NaCl}\end{array}$ & Phosphate buffered saline \\
\hline Elution volume & $500 \mu \mathrm{l}$ & $200 \mu \mathrm{l}$ & $500 \mu \mathrm{l}$ & $100 \mu \mathrm{l}$ \\
\hline Bound elution buffer & 0.1 M Glycine, pH 2.5 & Undisclosed buffer composition & 0.1 M Glycine, pH 2.5 & $\begin{array}{l}0.1 \mathrm{M} \text { Glycine-HCl, } \mathrm{pH} 2.5 \text {, } \\
\text { and Tween } 20\end{array}$ \\
\hline Elution volume & $500 \mu \mathrm{l}$ & $1000 \mu \mathrm{l}$ & $500 \mu \mathrm{l}$ & $300 \mu \mathrm{l}$ \\
\hline Commercial name & $\begin{array}{l}\text { ProteomLab IgY-HAS } \\
\text { (Beckman Coulter) }\end{array}$ & Hu-6HC (Agilent) & $\begin{array}{l}\text { ProteomLab IgY-12 } \\
\text { (Beckman Coulter) }\end{array}$ & ProteoPrep20 (SIGMA) \\
\hline Proteins removed & Albumin & $\begin{array}{l}\text { Albumin, IgG, IgA, transferrin, } \\
\alpha 1 \text {-antitrypsin, and haptoglobin }\end{array}$ & $\begin{array}{l}\text { Albumin, IgG, IgA, IgM, } \\
\text { transferrin, fibrinogen, } \\
\alpha \text { 2-macroglobulin, } \\
\text { a1-antitrypsin, } \\
\text { haptoglobin, } \\
\text { apolipoprotein A1, A2, } \\
\text { and orosomucoid }\end{array}$ & $\begin{array}{l}\text { Albumin, IgG, IgA, IgM, IgD, } \\
\text { transferrin, fibrinogen, } \\
\text { a 2-macroglobulin, } \\
\text { a1-antitrypsin, haptoglobin, } \\
\text { orosomucoid, ceruloplasmin, } \\
\text { apolipoprotein A1, A2, B, } \\
\text { complement C1q, C3, C4, } \\
\text { plasminogen, and prealbumin }\end{array}$ \\
\hline
\end{tabular}

dimension, $50 \mu \mathrm{g}$ of proteins were diluted in $125 \mu \mathrm{l}$ of rehydratation buffer (9.8 M urea 4\% CHAPS $50 \mathrm{mM}$ DTT and 0.5\% IPG buffer 4-7). IPG strips (Amersham ref 17-6001-10), $7 \mathrm{~cm}$, covering a $\mathrm{pH}$ range of $3-10$ were rehydrated with this solution during $18 \mathrm{~h}$ under low viscosity paraffin oil. For focalisation, the following voltage/time profile was used on a IPGPhor II: $300 \mathrm{~V}$ for $2 \mathrm{~h}$, a gradient until $1000 \mathrm{~V}$ for $1 \mathrm{~h}$, a gradient until $5000 \mathrm{~V}$ for $1 \mathrm{~h} 30$ and $5000 \mathrm{~V}$ during $3 \mathrm{~h} 30$. A total of $23250 \mathrm{Vh}$ was obtained. For the second dimension, strips were equilibrated for $30 \mathrm{~min}$ in $6 \mathrm{M}$ urea, 30\% glycerol, 2\% SDS, $50 \mathrm{mM}$ Tris $\mathrm{pH} 8.8,1 \%$ DTT and then incubated for an additional $30 \mathrm{~min}$ in the same solution except that DTT was replaced by $5 \%$ iodoacetamide. After equilibration, proteins were separated in the second dimension in 4-12\% NuPAGE gels (Invitrogen). Gels were stained with a silver nitrate procedure $[20,21]$ and scanned at 300 dots/in. using the Labscan 3 software (GE Healthcare) after a procedure of calibration using the kaleidoscope LaserSoft Imaging (Kodak Ref: R020123).

\subsection{SELDI-TOF analysis}

Each sample was diluted 1.5 times with a solution of $8 \mathrm{M}$ Urea, $1 \%$ CHAPS and shaken $15 \mathrm{~min}$ at room temperature. Denaturated samples equivalent to $40 \mu \mathrm{g}$ of protein were then mixed with $200 \mu$ l of array specific binding buffer.

The following binding buffers were used for washing and protein binding on the arrays: weak cationic exchange (CM10) with $100 \mathrm{mM}$ Ammonium Acetate $\mathrm{pH}$ 4, 0.1\% Triton and strong anion exchange array (Q10) with $100 \mathrm{mM}$ Tris, 0.1\% Triton $\mathrm{pH}$ 9.0. ProteinChips arrays were pre-equilibrated with $150 \mu \mathrm{l}$ of binding buffer in a 96 wells bioprocessor and incubated 5 min with gentle agitation. After removing binding buffers from the wells, denaturated samples were added and incubated for $1 \mathrm{~h}$ on a plate shaker at room temperature. The wells were washed two times with the binding buffer and one time with the binding buffer minus triton during $5 \mathrm{~min}$, followed by a final brief rinse with water. Proteinchip arrays were removed from the bioprocessor and air-dried. Finally, $0.8 \mu \mathrm{l}$ of saturated sinapinic acid solution was applied twice to each spot and the chips were allowed to air-dry again. Mass spectrometric analysis was performed by SELDI-TOF mass spectrometry in a PBS-IIc ProteinChip reader (Bio-Rad). All data collection settings were similar (calibration, focusing mass, laser intensity and detector sensitivity). Each spectrum was the result of an average of at least 100 laser shots and was externally calibrated with the All-in-1 Protein Standard II (Bio-Rad). Spectra analysis was carried out using the ProteinChip software version 3.2 (Bio-Rad). The background was subtracted using the default software settings. Peaks with a ratio signal/noise above 3 were identified by the ProteinChip Software. After normalization on Total Ion Current (TIC) and quantification, the data were exported to Hierarchical Clustering Explorer Software (HCE v3 [22]). Clusters were obtained using a Manhattan Distance test.

\subsection{Protein identification by MALDI-TOF}

Protein spots were excised from 1D gels and were washed in $15 \mu \mathrm{l}$ of $100 \mathrm{mM} \mathrm{NH} \mathrm{HCO}_{3}$ during $10 \mathrm{~min}$. After addition and incubation with $15 \mu \mathrm{l}$ of acetonitrile (ACN) during $10 \mathrm{~min}$, supernatants were removed and the procedure repeated. After speedvac treatment, spots were re-hydrated in $10 \mu \mathrm{l}$ of trypsin solution (15 ng/ $\mu$ l, Promega) and digested overnight at $25^{\circ} \mathrm{C}$ in $10 \mu \mathrm{l}$ of $100 \mathrm{mM} \mathrm{NH}_{4} \mathrm{HCO}_{3} 5 \mathrm{mM} \mathrm{CaCl}_{2}$ buffer. The tryptic peptides were extracted in a two-step procedure: the first step was composed of addition of $10 \mu \mathrm{l}$ of $100 \mathrm{mM} \mathrm{NH}_{4} \mathrm{HCO}_{3}$ and $10 \mu \mathrm{l}$ of ACN for $10 \mathrm{~min}$. This step was repeated twice and collected supernatants were pooled. The second step was represented by an incubation of $10 \mathrm{~min}$ with $10 \mu \mathrm{l}$ of $5 \%$ formic acid and an addition of $10 \mu \mathrm{l}$ of ACN for $10 \mathrm{~min}$. This step was repeated twice and the two supernatants were also pooled. After complete drying, the pellet was resuspended in $10 \%$ formic acid and was desalted by using Millipore ZipTip C18 columns (Milipore, Bedford, MA).

Mass of peptides was determined in the positive-ion reflector mode of an UltraFlex I MALDI-TOF-TOF mass spectrometer (Bruker Daltonics). Peptide mass fingerprint identification of proteins was performed by searching against the HUMAN entries of databases (SwissProt and TrEMBL) and by 
A

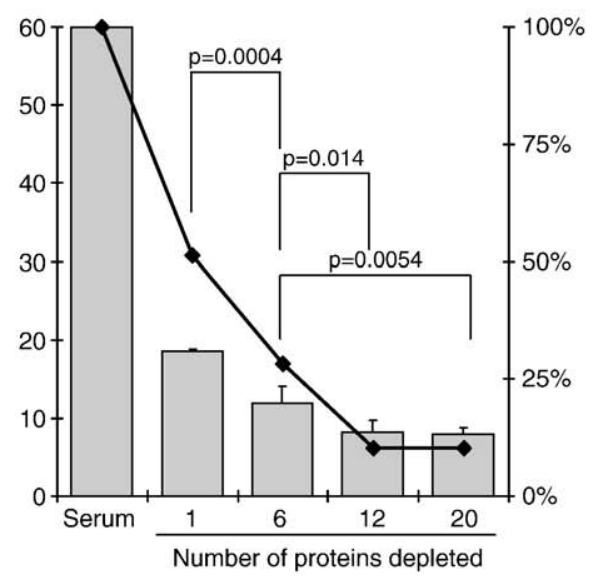

B Proteins

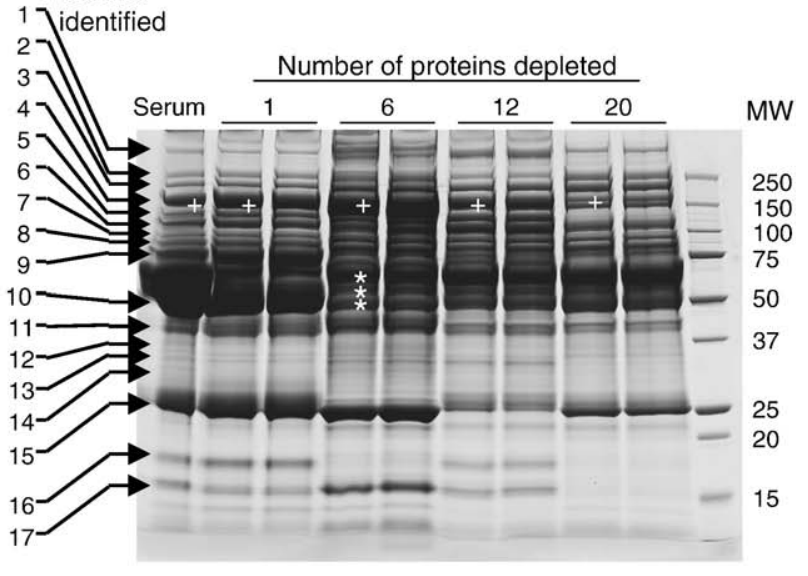

Fig. 1 - Comparison of the initial serum and the unbound fractions collected after depletion of 1, 6, 12 and 20 major blood proteins using commercial columns (Table 1). Panel A: The protein concentration $(\mathrm{g} / \mathrm{L})$ of the samples was measured with the BCA kit (Sigma) after buffer exchange. Results were obtained from 4 independent depletion experiments. The curve with the diamonds represents the theoretical amount of proteins remaining after depletion of the corresponding molecules. Statistical analysis were performed using the unpaired t test and were considered significant for a $p$ value of $<0.05$. Panel B: Coomassie stained SDS-PAGE gel of the samples ran in duplicate. A fixed amount of protein (60 $\mu \mathrm{g})$ was loaded per lane for all the samples. This amount corresponded to $1 \mu \mathrm{l}$ of the initial serum and $3.2 \mu \mathrm{l}, 5 \mu \mathrm{l}, 7.3 \mu \mathrm{l}$ and $7.5 \mu \mathrm{l}$ of serum equivalent for the column removing 1, 6, 12 and 20 proteins, respectively. The numbered arrows on the left indicated the bands that were selected for protein identification (Sup Table 1). Stars and crosses indicated bands that were specifically discussed in the text.
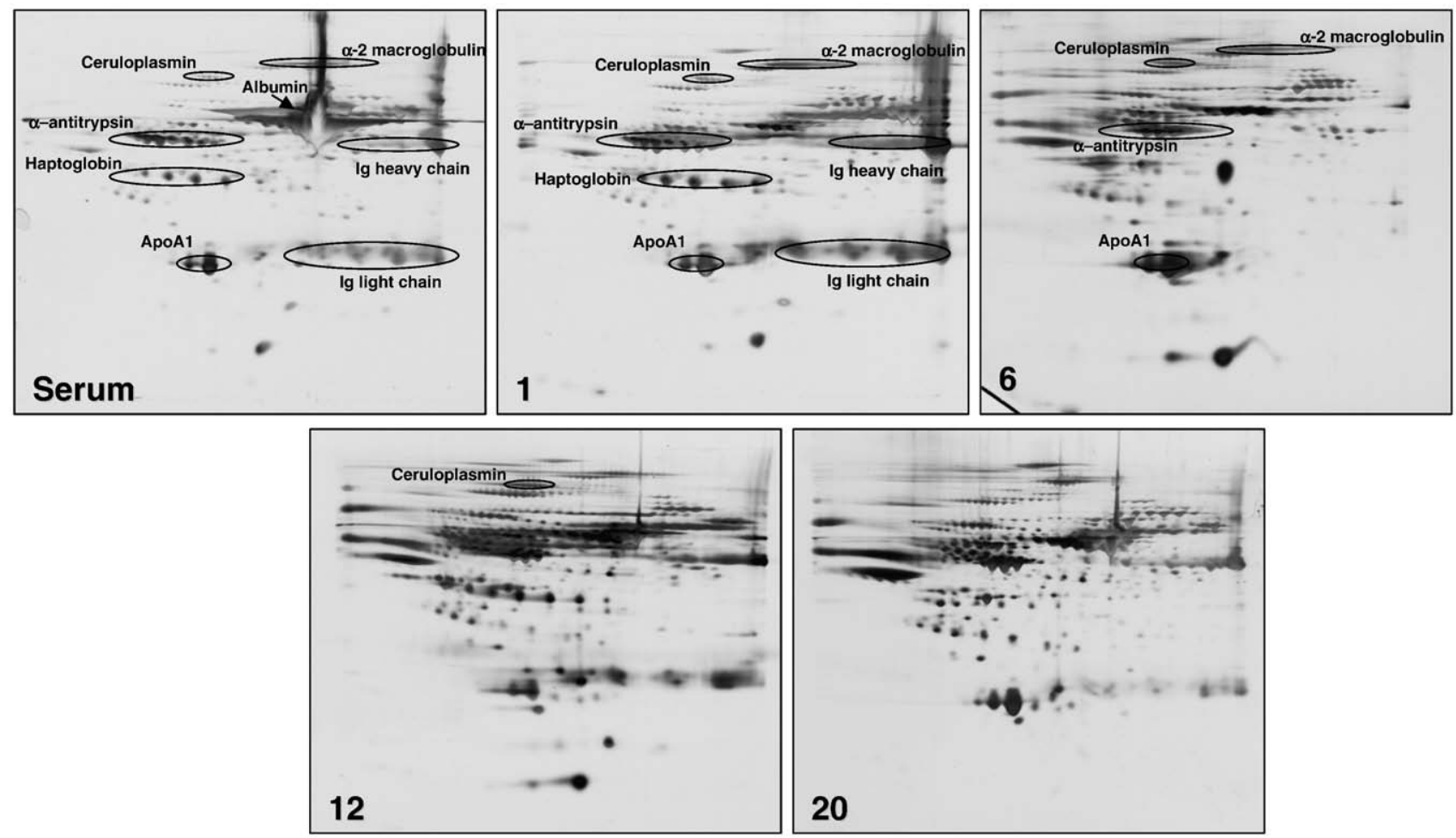

Fig. 2 - Silver stained 2D electrophoresis gels of the initial serum and the unbound fractions collected after depletion of 1, 6, 12 and 20 major blood proteins using commercial columns (Table 1). A fixed amount of protein (50 $\mu$ g) was analysed for all the samples. This amount corresponded to $0.8 \mu \mathrm{l}$ of the initial serum and $2.7 \mu \mathrm{l}, 4.2 \mu \mathrm{l}, 6.1 \mu \mathrm{l}$ and $6.3 \mu \mathrm{l}$ of serum equivalent for the column removing 1, 6, 12 and 20 proteins, respectively. 2D electrophoresis was performed form pH3 to $\mathrm{pH} 10$ in the horizontal dimension and from $150 \mathrm{kDa}$ to $15 \mathrm{kDa}$ in the vertical dimension. To illustrate the disappearance of series of proteins upon depletion, some spots were labeled based on our own proteomic identification (not shown) confirmed by data of the literature. 
Table 2 - Statistical analysis of SELDI-TOF peaks with signal/noise ratio above 3 detected on CM10 biochips.

\begin{tabular}{lcccc}
$\begin{array}{l}\text { Number of } \\
\text { proteins } \\
\text { depleted }\end{array}$ & $\begin{array}{c}\text { Number } \\
\text { of peaks } \\
\text { detected }\end{array}$ & $\begin{array}{c}\text { Minimal } \\
\text { SD }\end{array}$ & $\begin{array}{c}\text { Maximal } \\
\text { SD }\end{array}$ & $\begin{array}{c}\text { Mean } \\
\text { SD }\end{array}$ \\
\hline 0 (serum) & $18.8 \pm 1.3$ & $5.22 \%$ & $33.59 \%$ & $14.53 \%$ \\
1 & $27 \pm 1.4$ & $3.63 \%$ & $54.19 \%$ & $22.26 \%$ \\
6 & $29.5 \pm 1.7$ & $2.15 \%$ & $51.33 \%$ & $19.15 \%$ \\
12 & $30.8 \pm 0.5$ & $4.67 \%$ & $66.54 \%$ & $28.36 \%$ \\
20 & $26.5 \pm 1$ & $5.70 \%$ & $39.43 \%$ & $23.04 \%$ \\
\hline
\end{tabular}

Results were obtained from 4 independent depletion experiments of the same samples. (SD: standard deviation).

using the Mascot V 2.2 algorithm with one missing trypsin cleavage site and a mass tolerance of $50 \mathrm{ppm}$.

\section{Results and discussion}

\subsection{Quantification of unbound proteins}

The outcome of the capture was first controlled and quantified by evaluating the percentage of proteins recov- ered from each column (Fig. 1A). After immunocapture of 1, 6, 12 or 20 proteins (Table 1), unbound proteins represented respectively: $30.97 \% \pm 0.35,19.93 \% \pm 3.48,13.65 \% \pm 2.62$ and $13.28 \% \pm 1.26$ of the initial protein content. Reproducibility and recovery were in the range of what have been obtained before with the different columns $[16,17,23-25]$. The decrease in protein content followed the expected theoretical removal of proteins based on the normal serum protein composition (diamond curve, Fig. 1A). Statistical analysis confirmed significant differences in recovery between the columns, for all but the 12 and 20 columns. When compared to the 12 column, the 20 column removed 8 additional proteins (IgD, ceruloplasmin, apolipoprotein B, complement C1q, C3, C4, plasminogen, and prealbumin) (Table 1). It is important to note that all these proteins represent only a minor fraction of the total serum protein content. This explains why the difference between the amounts of unbound protein was not significantly different between the two columns [26]. Nevertheless, the higher diminution of the protein diversity brought out by the column removing 20 proteins could be interesting for further proteomic analyses.

\section{2. $1 \mathrm{D}$ and 2D electrophoresis protein profiles}

The efficiency and the reproducibility of the depletion were also evaluated by the duplicate analysis of the unbound protein
A

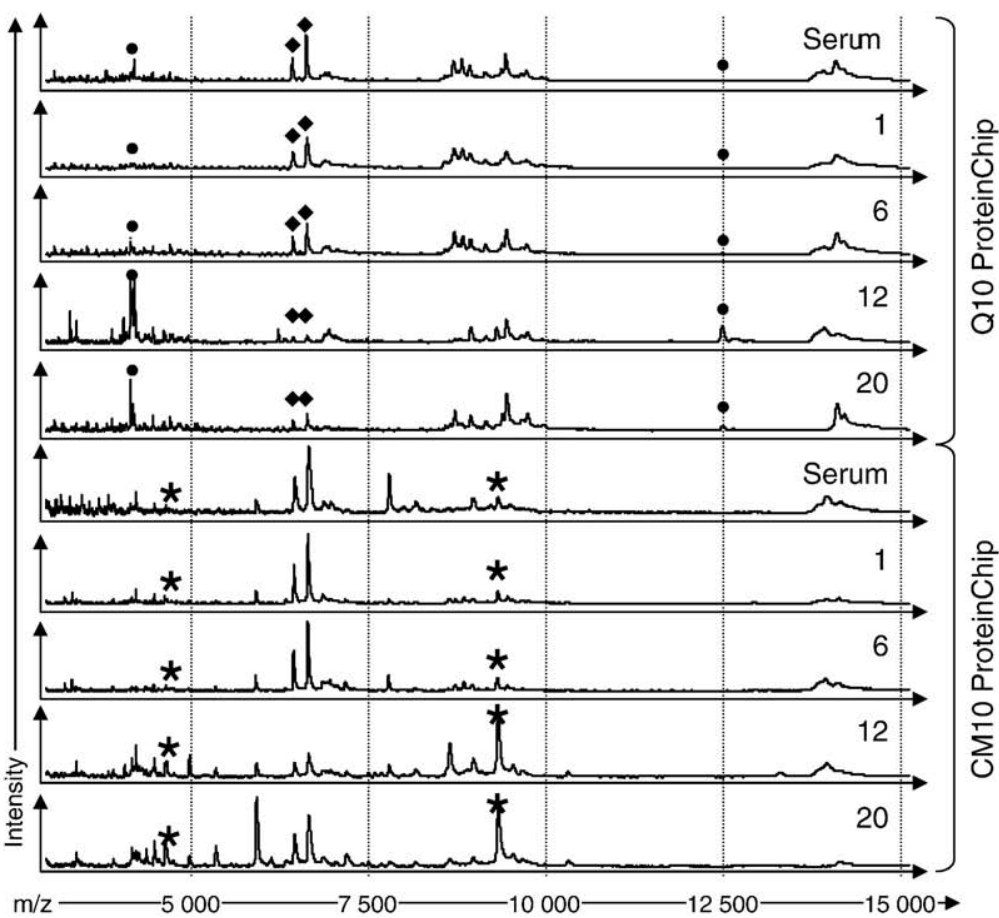

B

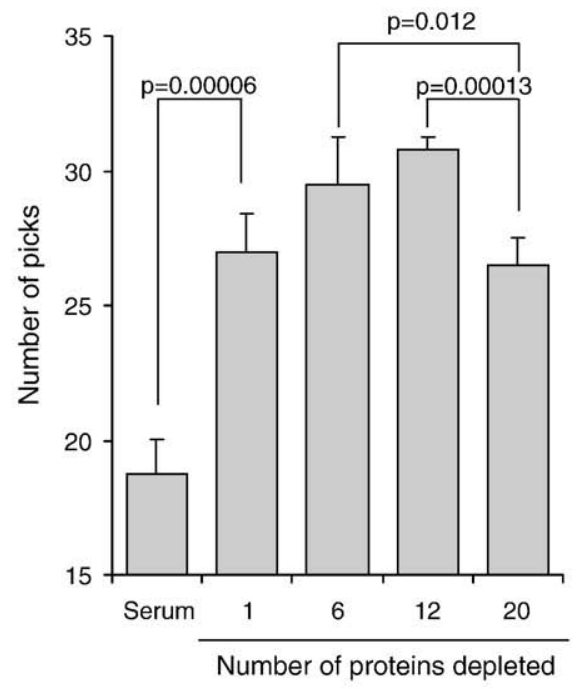

Fig. 3 - SELDI-TOF analysis. Panel A: SELDI-TOF spectra (between 2500 and 15,000 $\mathrm{m} / \mathrm{z}$ ) of the initial serum and the unbound fractions collected after depletion of 1, 6, 12 and 20 major blood proteins using commercial columns (Table 1). CM10 and Q10 proteinchips corresponding to anionic and cationic chromatographic surfaces were used. A fixed amount of protein (40 $\mu \mathrm{g})$ was analysed for all the samples. This amount corresponded to $0.7 \mu \mathrm{l}$ of the initial serum and $2.1 \mu \mathrm{l}, 3.3 \mu \mathrm{l}, 4.9 \mu \mathrm{l}$ and $5.0 \mu \mathrm{l}$ of serum equivalent for the column removing 1, 6, 12 and 20 proteins, respectively. Stars and diamonds indicated peaks which decreased or emerged along with the depletion. Panel B: Bar graph of the number of peaks with signal/noise ratio above 3 detected in the CM10 condition of the panel A. The data were compiled from 4 independent experiments. Statistical analysis were performed using the unpaired $t$ test and were considered significant for a $p$ value of $<0.05$. 


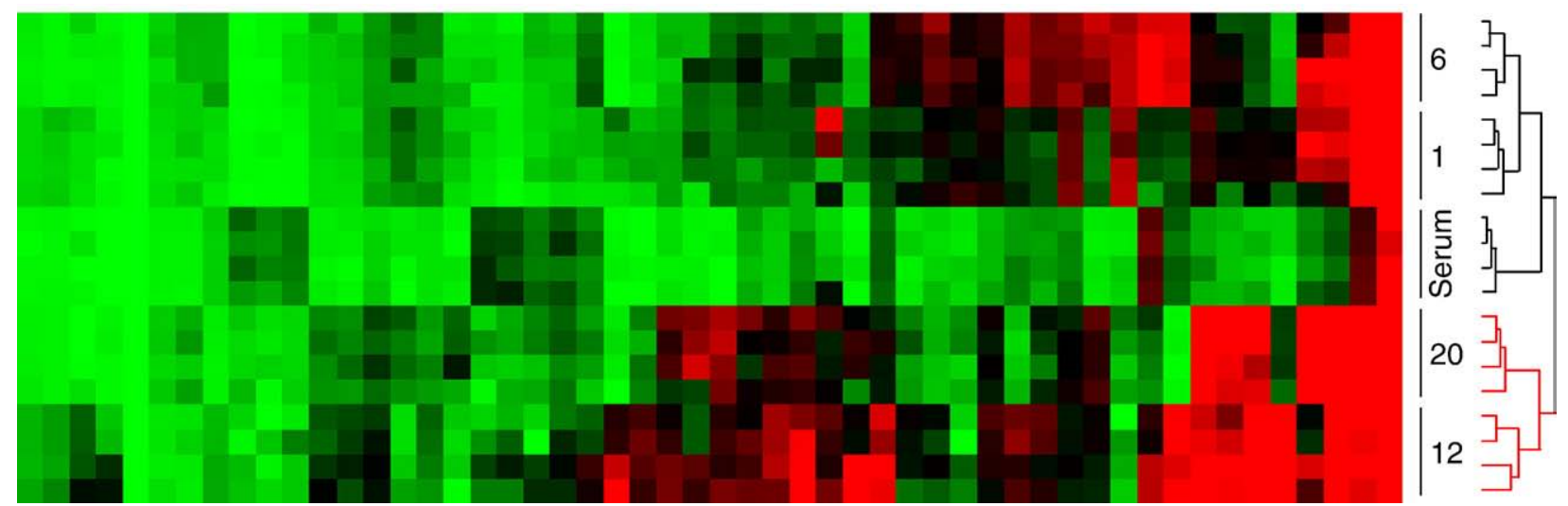

Fig. 4 - Hierarchical clustering of the SELDI-TOF peaks detected in the CM10 condition for the initial serum and the unbound fractions collected after depletion (see Fig. 3A). Clustering of the data generated with the Q10 chips were similar (not shown). The Manhattan distance was used as the correlation factor. Two main clusters were observed, one being composed by the 1 and 6 depleted protein profiles, and the second one by the 12 and 20 depleted protein profiles.

fractions on 1D NuPAGE gels (Fig. 1B). No obvious differences between duplicates were observed. Interestingly, the removal of a major protein, like albumin, clearly allowed the detection of new proteins as revealed by PMT and MALDI-TOF analysis (Fig. $1 B$, see Sup Table 1). In fact, after spot picking in the section of the gel where the albumin was located before its depletion (stars), $\alpha$-1-antichymotripsin, immunoglobulin $C$ gamma 1 and 2 could be identified. When 6,12 or 20 proteins were removed, additional proteins such as antithrombin-III, vitamin D-binding protein, $\alpha$-1-acid glycoprotein 1 and 2 could be detected (Sup Table 1). At the $\alpha 2$-macroglobulin position (cross), an additional protein (factor $\mathrm{H}$ complement protein) could be detected by PMT only after depletion of this protein by the two relevant columns (depleting 12 or 20 proteins).

Overall, these PMT results indicated that the removal of, at least 6 major proteins, allowed the detection of many low abundant components.

The interest of protein depletion was also illustrated by the 2DE analysis that clearly revealed, as demonstrated in many previous works, an increase in the number of spots detected after depletion, and a disappearance of known proteins (Fig. 2). The ability to detect more $2 \mathrm{D}$ spots seemed related to the capacity to load more equivalent serum on the gels, and to the "unmasking" of spots following the removal of major proteins.

\subsection{SELDI-TOF profiles}

To further address the proteomic complexity of the samples, unbound serum fractions were analysed using SELDI-TOF CM10 and Q10 ProteinChips (Bio-Rad). As illustrated Table 2 and Fig. 3 for $\mathrm{m} / \mathrm{z}$ ratio ranging from 2500 to 15,000, significantly more peaks with signal/noise ratio above 3 could be detected in the depleted fractions (Fig. 3). This is illustrated on low magnification spectra where some peaks decreased (Fig. 3A, diamonds) while others emerged along with the depletion (Fig. 3A, stars). Importantly, in our hand, the number of peaks detected after removal of 20 proteins was lower than that obtained with 6 or 12 proteins $(p=0.012$ and $p=0.00013)$.
This result might be related to the different commercial origins of the columns, or to the removal not only of the 20 selected proteins but also of peptides and proteins associated with them. Parallel analysis of the retained fractions (not shown) was however not informative to confirm this possibility.

As expected, the use of depletion columns that involved additional manipulation of the samples increased by at least $5 \%$ the variability of the data (Table 2). This was observed for all the columns and this needs to be taken into account in proteomic workflows including immunocapture. The global reproducibility of the SELDI-TOF analysis was however satisfactory with Pearson factors calculated for the same samples above 0.9 (Sup Table 2). Finally, hierarchical cluster analysis (HCE v3 [22]) of the SELDI-TOF data revealed the presence of two main clusters, one being composed by the 1 and 6 depleted protein profiles, and the second one by the 12 and 20 depleted protein profiles (Fig. 4). This distribution was confirmed by Pearson correlation factors (Sup Table 2).

\section{Conclusion}

Altogether, our results clearly confirmed the interest of depleting major blood proteins for the proteomic detection of low abundant components. However, we observed that increasing the number of depleted proteins from twelve to twenty had a limited beneficial impact and might increase drawbacks in removing associated peptides and proteins. This risk is linked to the fact that, in nondenaturing conditions, the immunocaptured proteins remained associated with an all range of peptides and proteins. In any case, in this study, as well as in a previous one using LC-MS/MS in CSF [19], the removal of 20 major proteins was more interesting than just removing 6 of them. The threshold between the gain of removing many proteins, and the drawbacks of removing associated proteins depend most likely on the design of the experiment, the analytical methods, and the choice between wanted and unwanted proteins removed. 


\section{Acknowledgements}

This study was supported by grants from the EC FP6 program cNEUPRO, the "Institut National contre le Cancer" (INCa), the CHRU of Montpellier and the CNRS.

\section{Competing interests}

For analytical evaluation, the protein depletion columns used in this study were provided by the different companies at a reduced price.

\section{Appendix A. Supplementary data}

Supplementary data associated with this article can be found, in the online version, at doi:10.1016/j.jprot.2009.03.008.

\section{R E F E R E N C E S}

[1] Anderson NL, Anderson NG. The human plasma proteome: history, character, and diagnostic prospects. Mol Cell Proteomics 2002;1(11):845-67.

[2] Rai AJ, Stemmer PM, Zhang Z, Adam BL, Morgan WT, Caffrey $\mathrm{RE}$, et al. Analysis of Human Proteome Organization Plasma Proteome Project (HUPO PPP) reference specimens using surface enhanced laser desorption/ionization-time of flight (SELDI-TOF) mass spectrometry: multi-institution correlation of spectra and identification of biomarkers. Proteomics 2005;5 (13):3467-74.

[3] States DJ, Omenn GS, Blackwell TW, Fermin D, Eng J, Speicher DW, et al. Challenges in deriving high-confidence protein identifications from data gathered by a HUPO plasma proteome collaborative study. Nat Biotechnol 2006;24 (3):333-8.

[4] Pieper R, Gatlin CL, Makusky AJ, Russo PS, Schatz CR, Miller SS, et al. The human serum proteome: display of nearly 3700 chromatographically separated protein spots on two-dimensional electrophoresis gels and identification of 325 distinct proteins. Proteomics 2003;3(7):1345-64.

[5] Yang Z, Hancock WS, Chew TR, Bonilla L. A study of glycoproteins in human serum and plasma reference standards (HUPO) using multilectin affinity chromatography coupled with RPLC-MS/MS. Proteomics 2005;5(13):3353-66.

[6] Clarke CH, Buckley JA, Fung ET. SELDI-TOF-MS proteomics of breast cancer. Clin Chem Lab Med 2005;43(12):1314-20.

[7] Tang N, Tornatore P, Weinberger SR. Current developments in SELDI affinity technology. Mass Spectrom Rev 2004;23 (1):34-44.

[8] Issaq HJ, Conrads TP, Janini GM, Veenstra TD. Methods for fractionation, separation and profiling of proteins and peptides. Electrophoresis 2002;23(17):3048-61.

[9] Guerrier L, Lomas L, Boschetti E. A simplified monobuffer multidimensional chromatography for high-throughput proteome fractionation. J Chromatogr B Analyt Technol Biomed Life Sci 2005;1073(1-2):25-33.

[10] Guerrier L, Thulasiraman V, Castagna A, Fortis F, Lin S, Lomas L, et al. Reducing protein concentration range of biological samples using solid-phase ligand libraries. J Chromatogr B Analyt Technol Biomed Life Sci 2006;833 (1):33-40.
[11] Thulasiraman V, Lin S, Gheorghiu L, Lathrop J, Lomas L, Hammond D, et al. Reduction of the concentration difference of proteins in biological liquids using a library of combinatorial ligands. Electrophoresis 2005;26(18):3561-71.

[12] Orvisky E, Drake SK, Martin BM, Abdel-Hamid M, Ressom HW, Varghese RS, et al. Enrichment of low molecular weight fraction of serum for MS analysis of peptides associated with hepatocellular carcinoma; 2006.

[13] Leatherbarrow RJ, Dean PD. Studies on the mechanism of binding of serum albumins to immobilized cibacron blue F3G A. Biochem J 1980;189(1):27-34.

[14] Birch RM, O'Byrne C, Booth IR, Cash P. Enrichment of Escherichia coli proteins by column chromatography on reactive dye columns. Proteomics 2003;3(5):764-76.

[15] Maccarrone G, Milfay D, Birg I, Rosenhagen M, Holsboer F, Grimm R, et al. Mining the human cerebrospinal fluid proteome by immunodepletion and shotgun mass spectrometry. Electrophoresis 2004;25(14):2402-12.

[16] Bjorhall K, Miliotis T, Davidsson P. Comparison of different depletion strategies for improved resolution in proteomic analysis of human serum samples. Proteomics 2005;5 (1):307-17.

[17] Roche S, Tiers L, Provansal M, Piva MT, Lehmann S. Interest of major serum protein removal for Surface-Enhanced Laser Desorption/Ionization-Time Of Flight (SELDI-TOF) proteomic blood profiling. Proteome Sci 2006;4:20.

[18] Liu T, Qian WJ, Mottaz HM, Gritsenko MA, Norbeck AD, Moore RJ, et al. Evaluation of multiprotein immunoaffinity subtraction for plasma proteomics and candidate biomarker discovery using mass spectrometry. Mol Cell Proteomics 2006;5(11):2167-74.

[19] Thouvenot E, Urbach S, Dantec C, Poncet J, Seveno M, Demettre E, et al. Enhanced detection of CNS cell secretome in plasma protein-depleted cerebrospinal fluid. J Proteome Res 2008;7(10):4409-21.

[20] Shevchenko A, Wilm M, Vorm O, Mann M. Mass spectrometric sequencing of proteins silver-stained polyacrylamide gels. Anal Chem 1996;68(5):850-8.

[21] Roche S, Delorme B, Oostendorp R, Barbet R, Caton D, Noel D, et al., Comparative proteomic analysis of human mesenchymal and embryonic stem cells: towards the definition of a mesenchymal stem cell proteomic signature. Proteomics 2009;9(2):223-32.

[22] Seo J, Bakay M, Chen YW, Hilmer S, Shneiderman B, Hoffman EP. Interactively optimizing signal-to-noise ratios in expression profiling: project-specific algorithm selection and detection $p$-value weighting in Affymetrix microarrays. Bioinformatics 2004;20(16):2534-44.

[23] Fu Q Garnham CP, Elliott ST, Bovenkamp DE, Van Eyk JE. A robust, streamlined, and reproducible method for proteomic analysis of serum by delipidation, albumin and IgG depletion, and two-dimensional gel electrophoresis. Proteomics 2005;5 (10):2656-64.

[24] Steel LF, Trotter MG, Nakajima PB, Mattu TS, Gonye G, Block T. Efficient and specific removal of albumin from human serum samples. Mol Cell Proteomics 2003;2(4):262-70.

[25] Huang L, Harvie G, Feitelson JS, Gramatikoff K, Herold DA, Allen DL, et al. Immunoaffinity separation of plasma proteins by IgY microbeads: meeting the needs of proteomic sample preparation and analysis. Proteomics 2005;5(13):3314-28.

[26] Roche S, Gabelle A, Lehmann S. Clinical proteomics of the cerebrospinal fluid: towards the discovery of new biomarkers. Proteomics Clin Appl 2008;2:429-36. 